\title{
Teeth as a Tool for Age Estimation: A Mini Review
}

\author{
Cheena Singh*1 and Kusum Singal ${ }^{2}$ \\ ${ }^{1}$ Assistant Professor, Department of oral medicine and radiology, PGIDS, India \\ ${ }^{2}$ Senior Research Fellow (SRF), Department of Genetics (Forensic science), India
}

Submission: December 01, 2017; Published: December 06, 2017

*Corresponding author: Dr. Cheena Singh*, Assistant Professor Department of Oral Medicine, Diagnosis and Radiology, PGIDS, Rohtak, Haryana, India, Tel: 9466737171; Email: kusumsingal731@gmail.com

\begin{abstract}
Every person of all ages (neonate, adolescent and adult) has right to be identified during death or alive. It can be either based on the dental (tooth) identification or by ante mortem records. With the help of forensic odontology now it has become easier to estimate the age in a very less time. Although age can be estimated by various methods but each method has a error rate which suggests its accuracy. In this article different methods of age estimation from teeth in adults (Human) will be discussed along with their formulas that can be applied to population to obtain desirable results.
\end{abstract}

Keywords: Adult Dental Age Estimation; Histopathological Methods; Coronal tooth index; Kvaal Method; Radiolographic Methods

\section{Introduction}

Age is the one of the essential factors to establish the identity of a human being. It becomes a challenging job to estimate age in adults when compared to adolescent age group. Ritz et al stated that adult growth completion and tooth eruption is also effected by many other factors such as nutrition, environmental factors etc. Tooth maturity is comparatively least effected by any exogenous factors as compared to its eruption [1]. Although age estimation is an archaic exercise that has been in practice from past decades by forensic anthropologists, scientists. But, nowa-days a new emerging branch known as "Forensic Odontology" is used to estimate age by using tooth/teeth. Because teeth are resistance to high temperature, any mass disaster. Because of this nature it is a unique age indicator.

Although there are various methods of age estimation in neonates, adolescents and adults. But in present article we will only discuss about the different methods of age estimation in adults using teeth along with the advantage, disadvantage of each method so that it can be concluded which method has high accuracy.

History of Age Estimation: The first attempt was made in England to use teeth as an indicator for age estimation. In the early 19th century, because of economic depression, juvenile work and criminality were serious social problems. A Dentist named Edwin Saunders was the first to publish information regarding dental implications in age assessment by presenting a pamphlet entitled "Teeth A Test of Age" to the English parliament in 1837 [2].
Need For Age Estimation: As already mentioned every person whether dead or alive has right to be identified for several reasons:-

I. Living person requires age estimation for-

a) Birth certificate is not available or records are doubtful.

b) To determine the age of a young or adult for criminal liability.

c) In case of illegal marriages.

II. Dead person requires age estimation for-

a) During disaster victim identification.

b) Aborted fetal age estimation.

\section{Methods of Age Estimation in Adults}

\section{Morphological Methods}

Gustafson's Method: Thoma 1944 described a histomorhogical method for age estimation in which 6 regressive changes were taken into consideration which are as follows:

a) Amount of occlusal Attrition of the incisal or occlusal surfaces due to mastication (A)

b) Coronary secondary dentine deposition $(\mathrm{S})$

c) Periodontitis (P)

d) Cementum apposition on root apex (C) 
e) Root resorption at apex (R)

f) Dentinal transparency of the root (T)

For each above mentioned 6 regressive changes a different scores ranging from 0-3 were assigned i.e. for regressive change (A) scores can be given are A0, A1, A2 and A3. Similar scores can be given for other five variables. Adding the allotted score for each variables (e.g. $\mathrm{A} 3+\mathrm{S} 2+\mathrm{P} 2+\mathrm{C} 1+\mathrm{R} 2+\mathrm{TI}=\mathrm{X}$ ) where $\mathrm{X}$ is total score after adding each variable. It has been noted that more the value of $\mathrm{X}$ and more is age.

\section{Age was estimated by Using Formula}

Age: $11.43+4.56 X$.

The error of estimation as calculated by Gustafson (1950) was \pm 3.6 years [3].

\section{Disadvantage:}

a. This method can only be applied on extracted tooth

b. None of variable can be used alone

c. Sectioning of teeth is relatively is time consuming
Kashyap and Koteswara Rao Method: They omitted periodontosis and root resorption from Gustafson's method and calculated the index values of various parameters undergoing regressive changes [4]. Their modified method gave an error of +1.59 years and Spearman coefficient value of 0.998 .

Maples and Rice Method: It was noticed that there are some miscalculations from this above mentioned formula of Gustafson [3]. Then to correct this new formula was designed to estimate age in adults which is as follows:

$$
\text { Age }=13.45+4.26 X
$$

Johanson Method: The improvements made by Johanson are widely accepted. In this method instead of 4 grades (0-3) seven grades were taken into consideration. Grades were $(0,0.5$, $1,1.5,2.0,2.5,3.0$ ) (Figure 1) and a multiple regression formula was proposed which is mentioned below:

Age $=11.02+(5.15 A)+(2.3 S)+(4.1 P)+(3.7 C)+(5.57 R)+(8.9 T)$

The error of estimation as calculated by Johanson was \pm 8 years [1-3].

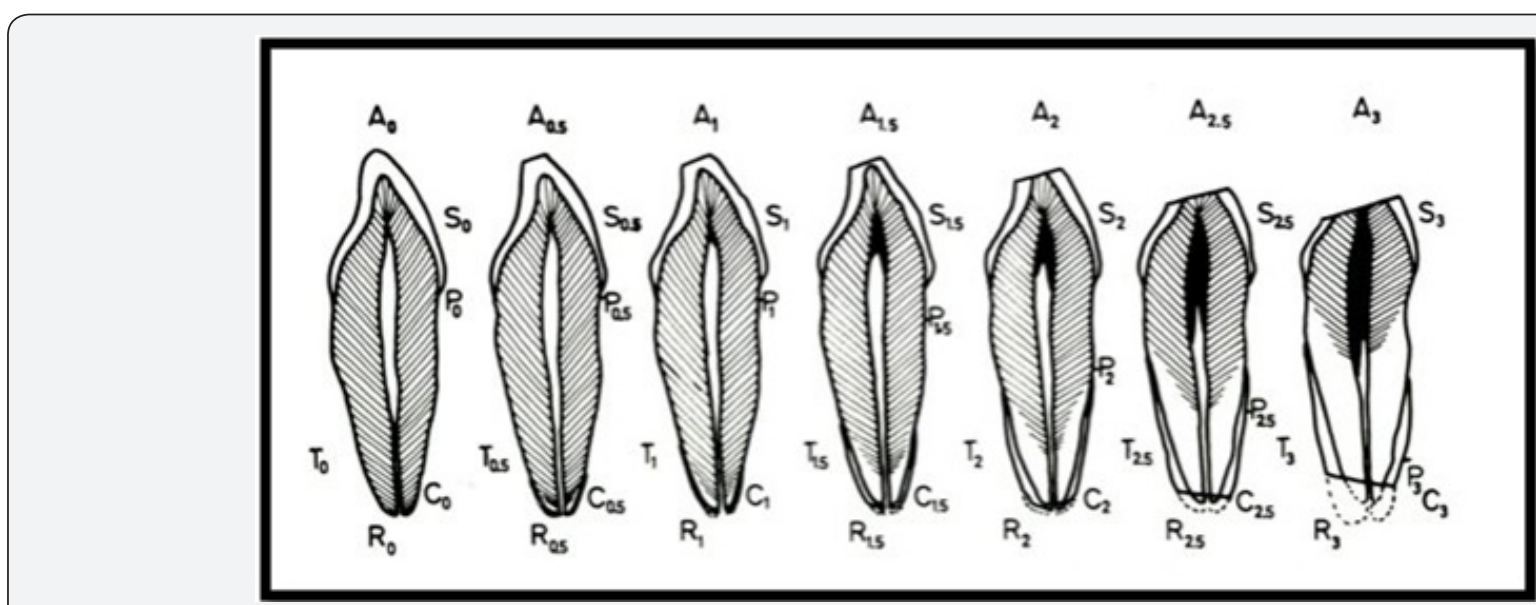

Figure 1: Gustafson's variable and the seven grades suggested by Johanson.

Solheim Method (1993): In this method along with five recommended changes of Gustafson (attrition, secondary dentin, periodontitis, cementum apposition, and root transparency) and added another three new changes were included. The three new age-related changes were surface roughness, color, and sex [3].

\section{Histological methods}

\section{Dentinal translucency- Bang and Ramm Method}

Bang and Ram were first to use dentinal translucency method alone for age estimation. They concluded that dentinal root translucency increases with age and stars to become visible during the 3rd decade of life beginning at apex and advancing coronally. This variation is due to decrease diameter of dentinal tubules caused by increased intratubular calcification [1,3].

As age increases dentinal translucency increases towards crown. Traditionally it is measured with help of vernier caliper
[5]. A new digital method was also described in 2014 to measure the dentinal transclucency [6]. Disadvantage of this method is that irregular junction of translucent and non translucent zones makes it difficult to measure the length.

Incremental Lines of Cementum: Kagerer and Grupe suggest that it is possible to estimate age using acellular cementum incremental lines. It is also suggested that hypominiralized bands in these incremental lines gave a indication of situations such as pregnancies, skeletal trauma, renal disorder etc [7]. Major disadvantage of this method is that is requires teeth to be extracted. So it is more feasible in case of dead people not in living being.

Average age of Attrition: A new method was introduced by $\mathrm{Li}$ and Ji in which they described the age with degree of attrition. They concluded that with age degree of attrition also increases [8]. 


\section{Radiological Method}

Schour and Masseler Method: In 1941, Schour and Masseler studied the development of deciduous and permanent teeth, describing chronological steps from 4 months to 21 years of age using radiographs and published the numerical development charts for them [9].

Moorees, Fanning and Hunt Method: In this method, the dental development was studied in the 14 stages of mineralization for developing single and multirooted permanent teeth and the mean age for the corresponding stage was determined. Moorees et al used panoramic radiographs or lateral oblique radiographs for their study [10].

Demirjian, Goldstein and Tanner Method: Demirjian, Goldstein and Tanner rated seven mandibular permanent teeth in the order of second molar (M2), first molar (M1), second premolar (PM2), first premolar (PM1), canine (C), lateral incisors (I2) and central incisor (I1) and determined eight stages (A to $\mathrm{H}$ ) of tooth mineralization together with stage zero for non appearance as follows. If there is no sign of calcification, the rating 0 is given; the crypt formation is not taken into consideration [11].

Kvaal method- PTR Method: In this method pulp size measurements of 6 teeth (maxillary central and lateral incisor, second premolar, mandibular incisor, canine and first premolar) from intraoral periapical radiograph was calculated. Measurements included several lenghth and width ratios [8]. Following age regression formula was used for age estimation:

$$
\text { Age }=129.8-316.4(M)-66.8(W-L)
$$

Where $\mathrm{M}$ is mean, $\mathrm{W}$ is width and $\mathrm{L}$ is length of tooth to be taken into consideration [12].

Coronal Pulp Cavity Index Method: The correlation between the reduction of the coronal pulp cavity and the chronological age was examined in a sample of 846 intact teeth from 433 individuals of known age and sex using panoramic $\mathrm{X}$-ray photographs [13].

Advanced Radiographic Techniques: Cone beam computed tomography (CBCT) a new developing and noninvasive technique can be used for age estimation which is based on pulp/tooth volume assessment $[14,15]$.

\section{Biochemical Methods}

Amino Acid Racemization: The relationship between dentinal age and the aspartic acid racemization in dentin was first suggested by Helfman and Bada [16]. Amino acids are also known as body building blocks which help in protein synthesis. Aspartic acid is a known amino acid which has rapid rate of racemization i.e. it gets spontaneously converted from one type to another (from dextrorotatory form to levorotatory type) with increasing age. These are basically found in brain, crystalline lens, bone and teeth. However it is high in root dentine. Thus teeth are considered to be a important source of age estimation in adults [17].

\section{Conclusion}

Forensic odontology is at infancy in India till today this can be either due to lack of awareness or level of knowledge of subject. This science also helps in age estimation by teeth in every age group. If we see mainly in adult age group various methods are present but every method has some error rate. However it is difficult to say that a particular method is best. It depends mainly on the circumstances and level of confirmation of result.

\section{References}

1. Ashith B Acharya, B Sivapathasundharam (2007) Forensic odontology In: Rajendran and B Sivapathasundharam editors Shafer's textbook of oral pathology. Elsevier 1199-1224.

2. Stavrianos C, Mastagas D, Stavrianou I, Karaiskou O (2008) Dental age estimation of adults: a review of methods and principles. Res J Med Sci 2: 258-268.

3. Priyadarshini C, Puranik MP, Uma SR (2015) Dental age estimation methods: a review Int J Adv Health Sci 1(12): 19-25.

4. Kashyap VK and Koteswara Rao NR (1990) A modified Gustafson method of age estimation from teeth. ForenSciInt 47: 237-247.

5. Ashith B. Acharya (2010) A new digital approach for measuring dentinal translucency in forensic age estimation. Am J Forensic Med Pathol 31: 133-137.

6. Ashith B. Acharya (2014) Forensic Dental age estimation by measuring root dentine translucency area using new digital technique. J Forensic Sci 59(3): 763-768.

7. Kagerer P and Grup G (2001) Age at death diagnosis and determination of life history parameters by incremental lines in human dental cementum as an identification aid. Forensic Sci Int 118: 75-82.

8. C Li, C Ji (1995) Age Estimation from permanent molar in northeast China by average age estimation. Forensic Science International 75: 89-196.

9. Schour I , Massler M (1941) Development of human dentition. J Am Dent Assoc 20: 379-427.

10. Moorees CF Fanning EA, Hunt EE (1968) Determination of age from formation stages of permanent teeth: J Dent Res 52: 264-273.

11. Demirjian A, Goldstein H, Tanner JM (1973) A new system of dental age assessment. Hum Biol 45: 211-227.

12. Kvaal SI, Kolltveit KM, Thomsen IO, Solheim T (1995) Age estimation of adults from dental radiographs. Forensic Science International 74: 175-185.

13. Drusini AG (2008) The coronal pulp cavity index: A forensic tool for age determination in human adults. Cuad Med Forensic 53: 235-249.

14. Yang F, Jacobs R, Willems G (2006) Dental age estimation through volume matching of teeth imaged by conebeam CT. Forensic Sci Int 159: 78-83

15. Singal K, Neelkamal (2017) Dental radiology: An adjunctive aid in age estimation. Annals and Essences of Dentistry 8c-11c.

16. Helfman, Bada JL (1976) Aspartic acid racemization in in dentin as a measure of ageing. Nature 262: 279-281.

17. AS Panchbhai (2011) Dental radiographic indicators a key to age estimation. Dentomaxillofacial Radiology 40: 199-212. 

(C) This work is licensed under Creative DOI : $10.19080 /$ JFSCI.2017.06.555695
Your next submission with Juniper Publishers will reach you the below assets

- Quality Editorial service

- Swift Peer Review

- Reprints availability

- E-prints Service

- Manuscript Podcast for convenient understanding

- Global attainment for your research

- Manuscript accessibility in different formats ( Pdf, E-pub, Full Text, Audio)

- Unceasing customer service

Track the below URL for one-step submission https://juniperpublishers.com/online-submission.php 